\title{
Talking rubbish
}

\section{Once upon a time you could just throw stuff away. It was called rubbish, or trash if you spoke American, and nobody much cared. Now though, talking rubbish is a serious business, says Stephen Hancocks.}

I $\mathrm{t}$ is probably fair to say that we don't have rubbish anymore, only things that are in a temporary phase of non-use. Far from discarding unwanted items have to spend time thinking about what they are and what they consist of, sorting them, almost filing all those no-longer wanted things so that they are able to be recycled. It began with newspapers. The local boy scouts would organise collections once a week or a couple of times a month. Then conscientious citizens piled up their dailies and used magazines on doorsteps while earnest-faced patrol-leaders pounded the neighbourhood loading up car boots and vans before heading off to the paper-plant to earn a few bob which they used to fix the leaks in the troop's scout hut roof. Next, we gradually moved to bottle-banks when the now familiar crash of smashing glass that punctuates our waking hours with hardly a conscious acknowledgement was a matter of regular comment as the empties were gleefully hurled in to shatter on the growing pile.

Now though almost everything in the practice and at home has to be scrutinised and graded: paper (ordinary or cardboard), glass (different colours - no tops please; but are they metal or plain junk?), metal (tin cans, lead, copper, molybdenum) (molybdenum?), plastic (all manner of polywhatnots and cycloco-ester hydrosproins), compostable (extra greeny-points for this), sharps (not usually at home), biohazard (similarly, unless you have some seriously secret hobbies) and then ... whatever is left must be rubbish surely? Not necessarily. Is it suitable for a charity shop or jumble sale, can it be broken into smaller parts to fit one or more of the other categories or is it just a yucky old dish cloth that really needs to be buried to rot away? Or does that make it compostable? Oh dear.

All this is very praiseworthy and doubtless reducing the planet's temperature by a fraction of a degree but it does lead to its own dilemmas. For example, does the energy required to purify and pump the extra water that you use rinsing out all those red wine bottles, yoghurt pots and pickle jars offset that saved by recycling them? Then again, even if you load everything into the car just once a month for a trip to the barrage of skips, holes, slots, flaps and containers that constitute the reclamation park, do the greenhouse gases that your vehicle emits more than cancel out the good that you have been doing for the last 28 days? How dreadful if the calculations mean that you can drive halfway there but then have to park and struggle the rest of the way with it all in carrier bags.

I wonder too if there are other losers in this new found zest for cutting out junk. What about primary and nursery schools who used to collect the famous toilet roll cores and squeezy washing-up liquid bottles in order for the children to make Blue Peter style models of pirate ships, clothes-peg holders or a hundred other items that thrilled parents at home time?

The other downside is the emergence of the recycling bore. This is the person, maybe a work colleague, maybe a neighbour or (perish the thought) a family member who has become evangelically obsessive about the need to save humankind by shredding margarine cartons to house urban badgers and turning car tyres into new homes for asylum seekers. You

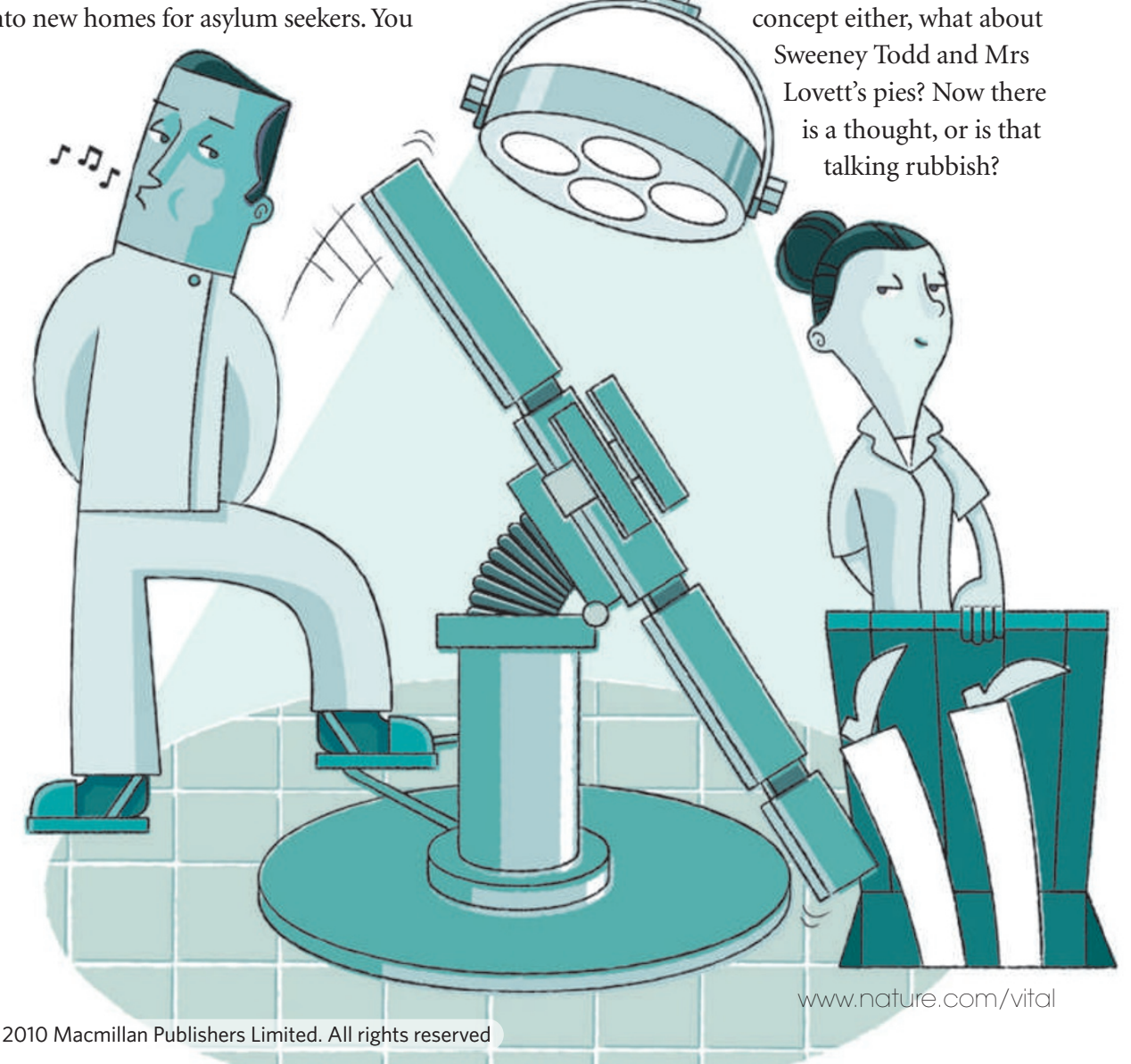

will know the sort instantly as they scold you in the staff room for not putting your lunchtime sandwich crusts out for the birds, for buying tomatoes in plastic trays instead of brown paper bags and even thinking of sending a postcard from holiday as the air-miles incurred compared to a quick message on Facebook are enough to rescue a small colony of puffins, despite being able to cut the stamp off for charity purposes and recycle the card. Or the dinner party guest who asks where everything has been bought, or rather 'been sourced from'. Woe betide you if you serve anything out of season, the peelings from which cannot be carried in a bucket to a nearby collection point for conversion into ethical motor fuel.

From time to time there are also things that you can't possibly recycle that you would really like to. Awkward patients for instance. How good would it be to be able to press a button and, Dr Who-like, transform the difficult individual in the chair or at the reception desk into a charming, pleasant and co-operative human being? But then again, I suppose that recycling customers isn't an entirely new concept either, what about a thought, or is that 